\title{
Asimilasi Suku Jawa dan Suku Tamil di Sei Serayu Gang Buntu, Kecamatan Medan Sunggal Sumatera Utara
}

\section{Assimilation of Javanesse and Tamil Tribe in Sei Serayu Buntu' Alley in Medan Sunggal District Sumatera Utara}

\author{
Mardiana Lestary, Rehia K.I Barus \& Armansyah Matondang \\ Program Studi Ilmu Komunikasi, Fakultas Ilmu Sosial dan Ilmu Politik \\ Universitas Medan Area, Indonesia
}

\begin{abstract}
Abstrak
Tujuan dari penelitian ini adalah untuk mengetahui komunikasi interpersonal dalam asimilasi suku Jawa dan suku Tamil di gang Buntu, untuk mengetahui asimilasi suku Jawa dan suku Tami di Sei Serayu gang Buntu, Kecamatan Medan Sunggal, Sumatera Utara, serta untuk mengetahui faktor apa saja yang menjadi penghalang dan pendukung asimilasi suku Jawa dan suku Tamil. Penelitian ini menggunakan teori asimilasi. Dalam mengumpulkan data peneliti melakukan wawancara tatap muka dengan empat informan yang diantaranya dua informan bersuku Tamil, dan dua informan bersuku Jawa. Penelitian ini menggunakan penelitian kualitatif dengan analisis deskriptif. Hasil penelitian ini adalah bahwa adanya perkawinan campuran antara suku Jawa dan suku Tamil serta adanya faktor toleransi dan kesamaan budaya antara dua suku tersebut

Kata Kunci: Komunikasi Interpersonal, Asimilasi, Perkainan Campuran
\end{abstract}

\begin{abstract}
The purpose of this study was to find out interpersonal communication in the assimilation of the Javanese and Tamil Groups in the dead alley, to find out the assimilation of Javanese tribes and Tamil tibes in Sei Serayu Buntu Alley, Medan Sunggal sub-district, North Sumatera, and to find out what factors were the barriers and supporters of the assimilation of Javanese and Tamil tribes. This study uses the assimilation theory. In collecting data, research conducted face to face interviews with four informants, including two Tamil informants, and two Javanese informants. This study uses skinative research with descriptive analysis. The results of this study are that there is a mixed marriage between the Javanese and Tamil tribes as well as a factor of tolerance and cultural similarity between the two tribes. Keywords: Interpersonal Communication, Assimilation, Mixed Marriages
\end{abstract}

How to Cite: Lestary, Mardiana. Barus, Rehia K.I. \& Matondang, Armansyah. (2019). Asimilasi Suku Jawa dan Suku Tamil di Sei Serayu Gang Buntu, Kecamatan Medan Sunggal Sumatera Utara. Jurnal Ilmu Pemerintahan, Administrasi Publik dan Ilmu Komunikasi (JIPIKOM), 2(1) 2020: 25-32,

*E-mail: mardianalestary@gmail.com

ISSN 2550-1305 (Online)

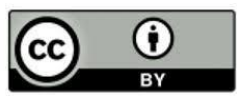




\section{PENDAHULUAN}

Interaksi dengan orang-orang yang berbeda kebudayaan merupakan pengalaman baru yang selalu dihadapi dan interaksi kadang menyebabkan terjadinya budaya baru. Penelitian yang dilakukan oleh Akmal Syafii Ritonga dalam judul Asimilasi Budaya Melayu Terhadap Budaya Pendatang di Kecamatan Senapelan Kota Pekanbaru, menggambarkan bagaimana proses pembauran (asimilasi) penduduk setempat yaitu Melayu dengan penduduk pendatang yaitu Minangkabau, Jawa, Tionghoa dan Batak. Proses asimilasi merupakan salah satu bentuk komunikasi antarbudaya yang terjadi pada masyarakat Indonesia yang memiliki beraneka ragam suku bangsa.

Salah satu interaksi yang terjadi di Sumatera Utara adalah suku Tamil dengan suku Jawa. BPS (2010) mencatat bahwa, Suku Tamil di Sumatera Utara ada 70.556 orang, sedangkan suku Jawa ada 4.319 .719 orang. Mayoritas suku Tamil terletak di jalan Teuku Cik Ditiro, Madras Hulu, Medan, Kota Medan Sumatera Utara. Sedangkan mayoritas suku Jawa terletak di Kecamatan Medan Sunggal. Awal mula masyarakat Jawa dan Tamil bisa berbaur sampai sekarang ini dengan membuka obrolan kecil yang mereka lakukan di warung. Terkait kehidupan bertetangga, masalah yang dihadapi suku Jawa kepada suku Tamil adalah saat masyarakat Tamil berbicara dengan tetangga lain, menggunakan bahasa yang tidak layak untuk diucapkan sehingga hal ini kemudin dicontoh oleh anak-anak sekitar. Sebaliknya masalah yang dihadapi Tamil kepada Jawa yaitu saat masyarakat Jawa berbicara terkadang membuat sakit hati warga Tamil.

Berdasarkan uraian latar belakang di atas maka dapat dirumuskan sebagai berikut: Bagaimana komunikasi interpersonal dalam suku Jawa dan suku Tamil di Sei Serayu gang Buntu Kecamatan Medan Sunggal, Sumatera Utara, Bagaimana asimilasi suku Jawa dan suku Tamil di Sei Serayu gang Buntu, Kecamatan Medan Sunggal, Sumatera Utara, dan Faktor apa saja yang menjadi penghalang dan pendukung asimilasi suku Jawa dan suku Tamil di Sei Serayu gang Buntu, Kecamatan Medan Sunggal Sumatera Utara.

Manusia merupakan makhluk sosial yang hidup sebagai individu dalam kelompok sosial, komunitas, organisasi dan masyarakat. Dalam kegiatan sehari - hari manusia akan berinteraksi satu sama lainnya baik itu secara interpersonal maupun antarpersonal. Secara etimologi (bahasa), kata "komunikasi berasal dari bahasa Inggris "communication" yang mempunyai akar kata dari bahasa latin "communicare". Kata communicare sendiri memiliki tiga arti yaitu: "to make common" atau membuat sesuatu jadi umum, kemudian "cum dan munus" berarti saling memberi sesuatu sebagai hadiah, dan yang terakhir yaitu membangun pertahanan bersama (Mufid, 2005). Menurut Harold D Laswell dalam (Mulyana, 2007) komunikasi dapat dibagi menjadi lima unsur yang saling berkaitan, diantaranya: Komunikator, Komunikan, Pesan, Saluran, Efek atau umpan balik, Gangguan. Komunikasi merupakan alat untuk membentuk identitas dan juga mengubah mekanisme. Kemudian secara luas komunikasi antarbudaya juga didefinisikan sebagai proses komunikasi dimana individuindividu yang memiliki perbedaan latar belakang kultur atau dimana sub kultur melakukan komunikasi secara kontak langsung dengan lainnya (Berger, 2014).

Komunikasi interpersonal secara umum adalah komunikasi antara orang- orang secara tatap muka, masing-masing orang yang terlibat dalam komunikasi tersebut saling 
mempengaruhi persepsi lawan komunikasinya. Komunikasi interpersonal adalah komunikasi antara orang-orang secara tatap muka, yang memungkinkan setiap pesertanya menangkap reaksi orang lain secara langsung baik secara verbal maupun nonverbal (Mulyana, 2005; Hasibuan, E.J, \& Indra M, 2017). Efektivitas komunikasi interpersonal dimulai dengan lima kualitas umum yaitu keterbukaan, empati, sikap mendukung, sikap positif, dan kesetaraan. Lima karakteristik komunikasi interpersonal yang efektif menurut (Devito, 2007; Ritonga, S.A. dan Effiati J.H, 2016). Menurut Jalaluddin (jalaluddin, 2009) tujuan komunikasi interpersonal bermacam-macam, diantaranya: Mengungkapkan perhatian kepada orang lain, Menemukan diri sendiri, Menemukan dunia luar, Membangun dan memelihara hubungan yang harmonis, Mempengaruhi sikap dan tingkah laku, Mencari kesenangan atau sekedar menghabiskan waktu, Menghilangkan kerugian akibat salah komunikasi. (Waridah, 2016 ).

Suku adalah bersifat askriptif (sejak lahir), yang sama coraknya dengan golongan umur dan jenis kelamin (Janti, 2009; Muda, I., 2015). Sehubung dengan suku Jawa yang ada di gang Buntu, maka perlu diketahui bahwa asal mula mereka datang ke daerah ini karena permukiman ini masih sangat sepi. Pada awal datangnya suku Jawa tersebut hanya sekitar 2 kepala keluarga saja. Tamil merupakan suku yang memiliki aneka ragam budaya yang menarik, khususnya dalam bentuk tarian, upacara adat dan sebagainya. Mereka datang setelah suku Jawa menetap selama 5 tahun. (Ritonga \& Hasibuan, 2016).

Asimilasi adalah proses yang ditandai adanya usaha mengurangi perbedaan yang terdapat diantara beberapa orang atau kelompok dalam masyarakat serta usaha menyamakan sikap, mental dan tindakan demi tercapainya tujuan bersama. Asimilasi timbul bila ada kelompok masyarakat dengan latar belakang kebudayaan yang berbeda saling bergaul secara intensif dalam jangka waktu lama, sehingga lamban laun kebudayaan asli mereka akan berbeda sifat dan wujudnya membentuk kebudayaan baru sebagai kebudayaan campuran (Setiadi \& Usman, 2011). Asimilasi terjadi dikarenakan dipengaruhi oleh 4 faktor (Turmanggor, 2010:65), yaitu: Faktor Toleransi, Faktor kemanfaatan timbal balik, Faktor Simpati, Faktor Perkawinan. Terdapat 8 faktor penghalang terjadinya asimilasi (Soekanto, 2005): 1) Terisolasi kehidupan suatu golongan tertentu dalam masyarakat (biasanya golongan minoritas); 2) Kurangnya pengetahuan mengenai kebudayaan yang dihadapi; 3) Perasaan takut terhadap kekuatan suatu kebudayaan yang dihadapi; 4) Perasaan bahwa suatu kebudayaan golongan atau kelompok tertentu lebih tinggi daripada kebudayaan golongan atau kelompok lainnya; 5) Dalam batas tertentu, perbedaan warna kulit atau perbedaan ciri-ciri badaniah; 6) In-group feeling yang kuat dapat pula menjadi penghalang berlangsungnya asimilasi; 6) Golongan minoritas mengalami gangguan dari golongan yang berkuasa; 7) Faktor perbedaan kepentingan ditambah dengan pertentangan pribadi dapat menghalangi proses asimilasi. (Hasibuan \& Indra).

Sedangkan faktor pendukung terjadinya asimilasi adalah: 1) Toleransi; 2) Kesempatan-kesempatan yang seimbang dibidang ekonomi; 3) Sikap menghargai orang asing dan kebudayaanya; 4) Sikap terbuka dari golongan yang berkuasa dalam masyarakat; 5) Persamaan dalam unsur-unsur kebudayaan; 6) Perkawinan Campuran; 6) Adanya musuh bersama di luar 


\section{METODE PENELITIAN}

Jenis penelitian ini adalah kualitatif dengan desain penelitian deskriptif kualitatif. Penelitian ini bertujuan untuk menggambarkan fenomena sosial yang ada dimasyarakat. Lokasi penelitian ini dilakukan di gang Buntu, Kecamatan Medan Sunggal. Waktu penelitian ini dilaksanakan selama 1 bulan yaitu tanggal 16 Mei 2019 hingga 16 Juni 2019. Adapun teknik pengumpulan data yang digunakan dalam penelitian ini adalah teknik wawancara, observasi dan dokumentasi. Miles dan Huberman (dalam Gunawan, 2013) mengemukakan tiga tahapan yang harus dikerjakan dalam menganalisis data penelitian kualitatif, yaitu: Reduksi data, Penyajian Data, dan Penarikan simpulan dan Verifikasi. Pengujian kredibiiltas data dengan melakukan, perpanjangan masa pengamatan, meningkakan ketekunan dalam penelitian, dan tringulasi.

\section{HASIL DAN PEMBAHASAN}

Dari hasil wawancara dengan keempat informan di Sei Serayu gang Buntu peneliti mendapatkan hasil dari faktor toleransi yang merupakan faktor pertama terjadinya asimilasi, Seperti yang dikatakan oleh Kalima, pada saat Idul Fitri ia tidak menghidupkan musik dirumahnya dan jika ia ingin menghidupkan musik maka dengan volume yang kecil dikarenakan takut terganggu oleh warga muslim lainnya. Menghargai hari besar umat yang berbeda agama adalah sikap yang selalu mereka wariskan ke anak-anak mereka. Informan ketiga tidak mempermasalahkan aroma dari Dupa yang dibakar oleh warga Tamil khususnya yang beragama Budha saat melaksanakan ibadah sembahyang. Ketika Tamil sedang melaksanakan ibadah dan membakar Dupa, informan ketiga tidak keluar rumah begitupun warga lainnya. Menurut hasil observasi yang telah dilakukan oleh peneliti selama satu bulan, bahwa toleransi yang terjadi di gang Buntu sangat tinggi.

Kemanfaatan timbal balik adalah memberikan manfaat kepada kedua belah pihak. Dari hasil wawancara dengan keempat informan, peneliti mendapatkan hasil dari faktor kemanfaatan timbal balik yang merupakan faktor kedua terjadinya asimilasi. Menurut informan empat, manfaat timbal balik yang ia rasakan seperti saling tolong-menolong. Seperti yang sudah dikatakan oleh Lusia bahwa kedekatan mereka secara emosional sangatlah akrab sudah seperti layaknya hubungan saudara kandung. Menceritakan keluh kesah antara satu dengan yang lain.

Dari hasil wawancara dengan keempat informan, peneliti mendapatkan hasil dari faktor simpati yang merupakan faktor ketiga terjadinya asimilasi. Informan pertama dan kedua mengatakan yang mereka lakukan adalah saat tetangga mereka sedang ditimpa musibah misalnya salah satu dari tetangga mereka meninggal dunia, informan satu dan dua langsung ke rumah dan sedikit memberikan sumbangan kepada keluarga yang ditinggalkan.

Informan satu, dua, tiga dan empat mengatakan bahwa di lingkungan ini terdapat perkawinan campuran antara bangsa India dengan bangsa Indonesia. Namun bangsa India berpindah agama menjadi Muslim karena mengikuti kepercayaan dari calon istrinya. Kemudian dalam melangsungkan pernikahan keturunan Jawa dan India maka akan ditemukan adanya perpaduan budaya campuran dari masyarakat India dan Jawa. Asimilasi melalui perkawinan yang mereka gunakan disesuaikan dengan tata cara Jawa salah satunya adalah pingitan. 
Terdapat 8 faktor penghalang terjadinya asimilasi, Dari hasil wawancara dengan keempat informan, peneliti mendapatkan hasil dari terisolasinya kehidupan suatu golongan minoritas di dalam masyarakat. Informan satu dan dua mengatakan bahwa saat pertama kali mereka tinggal di lingkungan ini mereka merasakan keanehan karena mayoritas di lingkungan ini adalah suku Jawa dan bahasa yang mereka sering dengar adalah bahasa Jawa. Setelah peneliti melakukan penelitian dan observasi selama satu bulan di gang Buntu, ternyata yang peneliti lihat bahwa di lingkungan tersebut golongan minoritas sudah tidak terisolasi lagi. Mereka bisa membaur dengan golongan la in begitupun sebaliknya.

Kurangnya ilmu pengetahuan mengenai kebudayaan yang sedang kita hadapi menjadi penghambat terjalannya asimilasi. Menurut informan dua bahwasannya ia tidak mengetahui banyak hal tentang kebudayaan suku Jawa hanya tentang kebudayaan dari pernikahan suku Jawa. Komunikasi interpersonal membantu seseorang untuk mendapatkan segala informasi penting dari orang lain termasuk informasi yang bersifat aktual. Seperti yang sudah dikatakan oleh Lusia diatas bahwa dia mendapatkan informasi seperti kebudayaan suku Jawa yang melakukan injak telur, menggunakan Kembar Mayang dan sebagainya didapat dari warga suku Jawanya langsung. Berbeda dengan informan ketiga, ia mengetahui kebudayaan dari suku Tamil hanya melalui televisi saja dan pengetahuannya pun tidak cukup banyak tentang kebudayaan Tamil.

Perasaan takut terhadap kekuatan suatu kebudayaan yang sedang dihadapi menjadi suatu penghalang tersendiri terjalinnya asimilasi. Menurut hasil observasi yang telah dilakukan oleh peneliti selama satu bulan melihat bahwa tidak semua kelompok merasa takut terhadap suatu kebudayaan yang sedang mereka hadapi, namun sebagian kelompok minoritas merasakan ketakutan dengan kebudayaan kelompok lain dengan alasan bahwa kebudayaan mereka makin lama akan mereka tinggalkan. Perasaan kebudayaan tertentu lebih tinggi daripada kebudayaan golongan lain membuat proses asimilasi menjadi tidak efektif dan terhalang. Dari hasil wawancara dengan keempat informan, peneliti mendapatkan hasil dari faktor tersebut yang merupakan faktor keempat penghalang asimilasi. Informan satu dan informan dua mengatakan bahwa kebudayaan dari suku jawa lebih tinggi dibandingkan kebudayaan lain di lingkungan.

Perbedaan warna kulit menjadi faktor penghalang terjadinya proses asimilasi. Informan ketiga dan keempat mengatakan bahwa mereka tidak pernah melihat ciri fisik maupun badaniah untuk melakukan proses pembauran. Karena menurut mereka semua manusia itu sama saja, hanya saja cuman beda warna kulitnya maupun sebagainya. Adanya perasaan yang kuat bahwa individu terikat pada kelompok dan kebudayaan kelompok yang bersangkutan. Dari hasil wawancara, peneliti mendapatkan hasil dari faktor perbedaan in-group feeling yang kuat yang merupakan faktor keenam penghalang asimilasi. Informan satu dan informan dua mengatakan bahwa dilingkungan ini terdapat individu yang tidak bisa lepas dari kelompok maupun kebudayaan kelompoknya. Golongan minoritas atau suku Tamil mengalami gangguan dari golongan yang berkuasa atau suku Jawa merupakan faktor penghalang terjalinnya asimilasi. Dari hasil wawancara dengan keempat informan, peneliti mendapatkan hasil dari faktor ketujuh penghalang asimilasi yaitu golongan minoritas mengalami gangguan dari golongan 
yang berkuasa. Informan satu dan informan dua mengatakan bahwa mereka tidak pernah mengalami gangguan dari golongan yang berkuas seperti suku Jawa.

Perbedaan kepentingan sering membuat proses asimilasi jadi tidak efektif, ditambah lagi dengan pertentangan pribadi masing-masing pihak. Informan satu dan informan dua mengatakan bahwa perbedaan kepentingan sudah biasa, karna setiap individu memiliki kepentingannya masing- masing. Baik informan satu maupun informan dua memiliki pertentangan pribadi masing-masing. Informan satu tidak memiliki musuh didalam lingkungan ini, namun informan dua memiliki musuh dan juga pernah bertengkar dengan individu yang bersangkutan yaitu yang bersuku Tamil. Informan ketiga dan informan keempat mengatakan bahwa terjadi perbedaan kepentingan antara mereka dengan tetangga sekitar. Dan mereka juga mempunyai musuh didalam lingkungan ini.

Terdapat 7 faktor pendukung terjadinya asimilasi, Toleransi bertujuan untuk mendapatkan kedamaian sebab toleransi merupakan sikap yang paling sederhana, tetapi mempunyai dampak yang positif bagi suatu Negara. Informan satu, dua, tiga dan empat mengatakan bahwa di lingkungan ini tidak pernah terjadi konflik yang besar dikarenakan perbedaan budaya maupun agama. Memiliki kesempatan dibidang ekonomi dengan kelompok yang berlatar belakang kebudayaan yang berbeda dapat mempercepat terjadinya proses asimilasi. Informan satu, dua, tiga dan keempat mengatakan bahwa sampai sekarang ini belum pernah melakukan usaha bersama dengan warga yang berbeda latar belakang. Di lingkungan ini kebanyakan warga membuka usahanya sendiri bersama keluarganya, tidak pernah bersama tetanggatetangga mereka.

Menghargai orang asing serta kebudayaannya membuat proses asimilasi cepat terjadi. Informan satu dan informan kedua mengatakan bahwa mereka menghargai orang asing yang belum dikenalnya. Seperti saat pertama kali menetap di lingkungan ini, sangat asing bagi mereka suasana maupun individunya, terlebih lagi individu tersebut berbeda latar belakang dari mereka. Menurut informan tiga dan empat karena mereka mayoritas di lingkun gan ini, mereka juga memiliki sikap menghargai orang asing dan kebudayaannya. Sikap terbuka dari golongan yang berkuasa dengan memberikan kesempatan kepada golongan minoritas membuat proses asimilasi berjalan lebih efektif. Informan satu dan informan dua mengatakan bahwa sikap yang terbuka dari golongan mayoritas membuat mereka lebih gampang melakukan pembauran. Informan ketiga dan informan keempat mengatakan bahwa mereka terbuka oleh semua tetangga mereka, dengan tujuan biar lebih mudah untuk melakukan suatu pembauran antara satu dengan yang lain.

Persamaan akan lebih mendekatkan antara golongan satu dengan golongan yang lainnya, Informan pertama dan kedua mengatakan bahwa terdapat kesamaan budaya antara Jawa dengan Tamil. Informan ketiga dan informan keempat mengatakan bahwa adanya kesamaan budaya antara suku Jawa dan suku Tamil dilihat dari adat pernikahan. Adanya kesamaan budaya antara dua suku yang berbeda membuat proses asimilasi atau pembauran menjadi lebih efektif. Perkawinan campuran terjadi apabila seseorang yang dari golongan tertentu menikah dengan golongan lain. Informan satu, dua, tiga dan 
empat mengatakan bahwa adanya perkawinan campuran antara kedua suku yaitu dari golongan mayoritas dan golongan minoritas. Adanya musuh bersama diluar membuat golongan mayoritas dan minoritas menjalin sebuah kompromi untuk menghadapi ancaman bersama diluar. Menurut informan satu, dua, tiga dan informan empat mengatakan bahwa mereka tidak memiliki musuh bersama baik di dalam lingkungan ini maupun diluar lingkungan ini.

Berdasarkan hasil penelitian, peneliti telah mengetahui dan mendapatkan data atau informasi yang konkrit dari keempat informan melalui wawancara penelitian mengenai asimilasi suku Jawa dan suku Tamil. Masyarakat suku Jawa dan suku Tamil melakukan komunikasi dengan komunikasi interpersonal. Hal ini dapat dilihat dari kedekatan antara satu dengan yang lain yang berbeda latar belakang. Dalam komunikasi interpersonal antara suku Jawa dan suku Tamil mereka sehari-hari berkomunikasi menggunakan bahasa Indonesia dalam berinteraksi dengan masyarakat sekitar. Masyarakat suku Tamil sudah menggunakan Bahasa Indonesia dalam kesehariannya dan meninggalkan bahasa Tamil yang merupakan bahasa yang dari kecil mereka gunakan.

Menurut Jalaluddin (2009) terdapat tujuh tujuan komunikasi interpersonal dimana peneliti hanya mengambil empat yang paling mendukung komunikasi interpersonal dalam asimilasi suku Jawa dan suku Tamil di Sei Serayu gang Buntu, diantaranya adalah, menemukan dunia luar, Maksudnya adalah bahwa komunikasi interpersonal bertujuan untuk mendapatkan berbagai informasi dari orang lain, Seperti yang sudah dijelaskan pada bagian hasil penelitian bahwasannya suku Tamil mendapatkan suatu pengetahuan baru dimana mereka mengetahui adat-adat apa saja yang digunakan suku Jawa saat mengadakan upacara adat pernikahan.

Manusia tidak dapat hidup sendiri perlu bekerja sama dengan orang lain. Semakin banyak teman yang diajak bekerja sama maka semakin lancarlah pelaksanaan kegiatan dalam kehidupan sehari-hari. Membangun dan memelihara hubungan yang harmonis sesama tetangga sudah diterapkan dan terjalin sejak lama antara suku Jawa dengan suku Tamil. Komunikasi interpersonal ialah proses penyampaian suatu pesan oleh seseorang kepada orang lain untuk memberitahu atau mengubah sikap, pendapat atau perilaku baik secara langsung maupun tidak langsung (dengan menggunakan media). Dalam asimilasi suku Jawa dan suku Tamil di Sei Serayu gang Buntu terdapat sikap saling mempengaruhi dari suatu kegiatan komunikasi antarpribadi tersebut, seperti suku Tamil yang sudah tidak berbicara menggunakan kata kotor lagi yaitu dengan menyebutkan kata-kata binatang saat berbicara.

Ada kalanya seseorang melakukan komunikasi interpersonal sekedar mencari kesenangan atau hiburan. Setelah peneliti turun langsung ke lapangan ditemukan bahwa interaksi dan komunikasi yang mereka lakukan setiap hari di gang Buntu hanya untuk mengisi waktu luang mereka di rumah, percakapan yang mereka bahas pun tidak selalu tentang isu politik, ekonomi budaya melainkan masalah-masalah yang mereka hadapi setiap harinya di rumah dan ada juga yang terkadang meminta pendapat tetangganya untuk tema perayaan ulang tahun anaknya. Kegiatan komunikasi antarpribadi yang 
mereka lakukan semata-mata untuk menghabiskan waktu bersama tetangganya dan dengan begitu hubungan antara kedua suku tersebut semakin dekat.

\section{SIMPULAN}

Komunikasi interpersonal dalam asimilasi suku Jawa dan suku Tamil di Sei Serayu gang Buntu berjalan dengan sangat baik antara suku Jawa dan Suku Tamil. Saling berinteraksi dengan membangun dan memelihara hubungan yang harmonis, sehingga berpengaruh kepada sikap dan tingkah laku mereka dalam berkomunikasi. Asimilasi yang terjadi antara Suku Jawa dan Suku Tamil terjadi dengan sangat baik. Meskipun suku Jaa merupakan suku mayoritas namun toleransi yang ada antara suku Jawa dan suku Tamil sangat tinggi. Sehingga akan timbul ikatan persaudaraan diantara keduanya, tidak jarng juga terjadi perkawinan diantara suku jawa dan Suku Tamil.

Faktor penghalang terjadinya asimilasi antara Suku Jawa dan Suku Tamil yaitu adanya perbedaan warna kulit dan adanya masalah pribadi yang pernah dialami oleh para informan dalam pergaulannya. Sedangkan faktor pendukung terjadinya asmilasi antara Suku Jawa dan Suku Tamil adalah sikap yang saling bertoleransi dalam hal keagamaan dan gotong royong, adanya persamaan budaya antara Suku Jawa dan Suku Tamil serta terjadinya perkawinan campuran yang terjadi antara Suku Jawa dan Suku tamil.

\section{DAFTAR PUSTAKA}

Berger, C. (2014). Handbook Ilmu Komunikasi The Handbook of Communication Science. Bandung: Nusa Media.

Devito, J. (2007). Komunikasi Antar Manusia. Tanggerang: Karisma Publishing Group.

Gunawan, I. (2013). Metode Penelitian Kualitatif Teori dan Praktek. Jakarta: Bumi Aksara.

Hasibuan, E.J, \& Indra M, (2017) Komunikasi Antar Budaya pada Etnis Gayo dengan Etnis Jawa, Jurnal Simbolika: Research and Learning in Comunication Study, 3 (2): 106-113

jalaluddin, R. (2009). Psikologi Komunikasi. Bandung: PT. Remaja Rosdakarya.

Janti, S. (2009). Pendidikan Kewarganegaraan Untuk Mahasiswa. Jakarta: Graha Ilmu.

Muda, I., (2015), Komunikasi Lintas Etnis di Pulau Weh-Sabang, Jurnal Simbolika: Research and Learning in Comunication Study, 1 (2): 158-165

Mufid, M. (2005). Komunikasi dan Regulasi Penyiaran. Jakarta: Kencana Prenada Media Group.

Mulyana, D. (2005). Ilmu Komunikasi: Suatu Pengantar. Bandung: Remaja Rosda Karya.

Mulyana, D. (2007). Ilmu Komunikasi, Suatu pengantar. Bandung: Remaja Rosda Karya.

Ritonga, S.A. dan Effiati J.H, (2016), Komunikasi Interpersonal Guru dan Siswa dalam Mengembangkan Bakat dan Kreativitas Anak Autis di SLB Taman Pendidikan Islam (TPI) Medan, Jurnal Simbolika: Research and Learning in Comunication Study. 2 (2): 188-199

Setiadi, E., \& Usman, K. (2011). Pengantar Sosiologi Pemahaman Fakta dan Gejala Permasalahan Sosial, Teori, Aplikasi dan Pemecahannya. Jakarta: Kencana.

Soekanto, S. (2005). Sosiologi Suatu Pengantar. Jakarta: PT. Raja Grafindo Persada.

Turmanggor, R. (2010). Ilmu Sosial dan Budaya Dasar. Jakarta: Kencana.

Ritonga, S.A. dan Hasibuan, E.J, (2016), Komunikasi Interpersonal Guru dan Siswa dalam Mengembangkan Bakat dan Kreativitas Anak Autis di SLB Taman Pendidikan Islam (TPI) Medan, Jurnal Simbolika: Research and Learning in Comunication Study. 2 (2): 188-199

Waridah, (2016), Berkomunikasi Dengan Berbahasa Yang Efektif dapat Meningkatkan Kinerja, Jurnal Simbolika: Research and Learning in Comunication Study. 2 (2): 231-239

Hasibuan, E.J, \& Muda I, (2017) Komunikasi Antar Budaya pada Etnis Gayo dengan Etnis Jawa, Jurnal Simbolika: Research and Learning in Comunication Study, 3 (2): 106-113 